\title{
Blocking L-type calcium channels reduced the threshold of cAMP-induced steroidogenic acute regulatory gene expression in MA-10 mouse Leydig cells
}

\author{
Akhilesh K Pandey ${ }^{1}$, Wei Li ${ }^{1}$, Xiangling Yin ${ }^{2}$, Douglas M Stocco ${ }^{3}$, Paula Grammas ${ }^{1}$ and XingJia Wang ${ }^{1}$ \\ ${ }^{1}$ Garrison Institute on Aging, ${ }^{2}$ Department of Neuropsychiatry and ${ }^{3}$ Department of Cell Biology and Biochemistry, Texas Tech University Health Sciences Center, \\ Lubbock, Texas 79430, USA \\ (Correspondence should be addressed to X Wang; Email: xingjia.wang@ttuhsc.edu)
}

\begin{abstract}
Previous studies have reported the roles of $\mathrm{Ca}^{2+}$ in steroidogenesis. The present study has investigated an inhibitory effect of $\mathrm{Ca}^{2+}$ influx through L-type $\mathrm{Ca}^{2+}$ channels on gene expression of steroidogenic acute regulatory (STAR) protein that regulates the transfer of substrate cholesterol to the inner mitochondrial membrane for steroidogenesis. Blocking $\mathrm{Ca}^{2+}$ influx through L-type $\mathrm{Ca}^{2+}$ channels using the selective $\mathrm{Ca}^{2+}$ channel blocker, nifedipine, markedly enhanced cAMP-induced STAR protein expression and progesterone production in MA-10 mouse Leydig cells. This was confirmed by utilization of different L-type $\mathrm{Ca}^{2+}$ channel blockers. Reverse transcription-PCR analyses of Star mRNA and luciferase assays of Star promoter activity indicated that blocking $\mathrm{Ca}^{2+}$ influx through L-type $\mathrm{Ca}^{2+}$ channels acted at the level of Star gene transcription. Further studies showed that blocking the $\mathrm{Ca}^{2+}$ channel enhanced Star
\end{abstract}

gene transcription by depressing the expression of DAX-1 (NR0B1 as listed in the MGI Database) protein, a transcriptional repressor of Star gene expression. It was also observed that there is a synergistic interaction between nifedipine and cAMP. Normally, sub-threshold levels of cAMP are unable to induce steroidogenesis, but in the presence of the L-type $\mathrm{Ca}^{2+}$ channel blocker, they increased STAR protein and steroid hormone to the maximal levels. However, in the absence of minimal levels of cAMP, none of the L-type $\mathrm{Ca}^{2+}$ channel blockers are able to induce Star gene expression. These observations indicate that $\mathrm{Ca}^{2+}$ influx through L-type $\mathrm{Ca}^{2+}$ channels is involved in an inhibitory effect on Star gene expression. Blocking L-type $\mathrm{Ca}^{2+}$ channel attenuated the inhibition and reduced the threshold of cAMPinduced Star gene expression in Leydig cells.

Journal of Endocrinology (2010) 204, 67-74

\section{Introduction}

Steroidogenesis in testicular Leydig cells is mainly regulated by $\mathrm{LH}$ secreted from the pituitary gland. Binding of $\mathrm{LH}$ to its receptor on Leydig cells induces cAMP-dependent signaling and cAMP-independent signaling. These signaling pathways act in concert to regulate steroidogenesis through their effects on the expression or activity of steroidogenic proteins in Leydig cells (Payne \& Youngblood 1995, Cooke 1999, Wang \& Stocco 1999).

In these signaling pathways, $\mathrm{Ca}^{2+}$-mediated signaling has been reported to play an important role in steroidogenesis. LH or human chorionic gonadotropin (hCG) stimulation of Leydig cells increases $\mathrm{Ca}^{2+}$ influx (Sullivan \& Cooke 1986, Kumar et al. 1994). In the absence of $\mathrm{Ca}^{2+}, \mathrm{LH}-$ or cAMP-stimulated testosterone production is reduced. Also, the reduced testosterone levels could be restored by the addition of $\mathrm{Ca}^{2+}$ to the culture medium (Janszen et al. 1976, Ramnath et al. 1997).
Further studies suggest that $\mathrm{Ca}^{2+}$ affect the transfer of the substrate cholesterol to the inner mitochondrial membrane, the rate-limiting step in steroidogenesis (Hall et al. 1981, Meikle et al. 1991). This was confirmed by a study reporting a $\mathrm{Ca}^{2+}$-induced increase in steroidogenic acute regulatory (STAR) protein (Manna et al. 1999), which is critical for the cholesterol transfer to the inner mitochondrial membrane to initiate steroidogenesis (Clark et al. 1994, Lin et al. 1995, Wang et al. 1998). While hCG-induced STAR protein expression and steroid production are enhanced by $\mathrm{Ca}^{2+}$, the increases in STAR protein and steroid hormone are reversed by calcium chelators. In addition, the effect of $\mathrm{Ca}^{2+}$ on hCG-induced Star mRNA expression is suppressed by blocking L-type $\mathrm{Ca}^{2+}$ channels using a blocker, verapamil (Manna et al. 1999).

However, observations on the roles of L-type $\mathrm{Ca}^{2+}$ channels in Star gene expression and steroidogenesis were not consistent in the previous studies. While blocking $\mathrm{Ca}^{2+}$ influx through L-type $\mathrm{Ca}^{2+}$ channels attenuates the progesterone production enhanced by the flavonoid, 
quercetin, it does not affect the increase in Star promoter activity in MA-10 mouse Leydig cells (Chen et al. 2007). Also, a previous study reported that androgen production is unaffected by L-type $\mathrm{Ca}^{2+}$ channel blockers at concentrations $<0 \cdot 1 \mathrm{mM}$ (Moger 1983). The data from the study show that blocking L-type $\mathrm{Ca}^{2+}$ channel produces a biphasic effect on steroidogenesis, with LH-induced androgen production being increased to the maximal levels and then reduced, as the concentration of verapamil in the cultures is increased. It is possible that the concentrations of L-type $\mathrm{Ca}^{2+}$ channel blockers, levels of tropic hormones or extraand intra-cellular $\mathrm{Ca}^{2+}$ status alter the effects of $\mathrm{Ca}^{2+}$ influx through L-type $\mathrm{Ca}^{2+}$ channels on Star gene transcription and steroid production. It was also observed that $\mathrm{Ca}^{2+}$ is an inhibitor of hCG-activated adenylate cyclase activity in MA-10 mouse Leydig cells (Pereira et al. 1988). This inhibitory effect may reduce cAMP formation and attenuate hCG-stimulated Star gene expression. Therefore, further studies are required to understand the roles of L-type $\mathrm{Ca}^{2+}$ channel in Star gene expression. The present study has investigated an inhibitory effect generated by $\mathrm{Ca}^{2+}$ influx through L-type $\mathrm{Ca}^{2+}$ channel on Star gene transcription in MA-10 mouse Leydig cells.

\section{Materials and Methods}

\section{Reagents}

$N^{6}, 2^{\prime}$-dibutyryl cAMP (dbcAMP), H89, and Waymouth's $\mathrm{MB} / 752$ medium were purchased from Sigma. H8 was purchased from EMD Chemicals (Gibbstown, NJ, USA). Nifedipine, verapamil, isradipine, and diltiazem were purchased from BIOMOL (Plymouth Meeting, PA, USA). Rabbit antiserum generated against STAR protein was a generous gift from Dr D B Hales (University of Illinois, Chicago; Hales et al. 2000). The monoclonal antibody against DAX-1 (NR0B1 as listed in the MGI Database) protein was a generous gift from Dr E Lalli (Institut de Pharmacologie Moléculaire et Cellulaire, Valbonne, France). Donkey antirabbit $\mathrm{IgG}$ antibody conjugated with HRP was purchased from Biosource (Camarillo, CA, USA). Horse serum was purchased from Invitrogen. The Dual-Luciferase Reporter Assay System was purchased from Promega. Other common chemicals used in this study were obtained from either Sigma or Fisher Chemicals (Pittsburgh, PA, USA).

\section{$M A-10$ cell culture}

The MA-10 mouse Leydig tumor cell line was a generous gift from Dr Mario Ascoli (University of Iowa, Iowa City). The cells were cultured in 12-well culture plates in Waymouth's $\mathrm{MB} / 752$ medium containing 15\% horse serum as previously described (Ascoli 1981), in an incubator at $37^{\circ} \mathrm{C}$ and $5 \%$ $\mathrm{CO}_{2}$. Before each experiment, the medium was replaced with serum-free Waymouth's medium.

\section{Steroid hormone production}

MA-10 cells were cultured for $30 \mathrm{~min}$ in serum-free Waymouth's medium with or without L-type $\mathrm{Ca}^{2+}$ channel blockers (as described in the figure legends), and then $0.05 \mathrm{mM}$ dbcAMP was added to the culture for $6 \mathrm{~h}$. The medium was collected at the end of each experiment and stored at $-20{ }^{\circ} \mathrm{C}$. The concentration of progesterone in the medium was determined by RIA (Resko et al. 1974).

\section{Western blot analysis}

Western blot analyses were performed to detect STAR protein and DAX-1 protein in MA-10 cells as previously described (Townson et al. 1996). Western blot analysis experiments were repeated at least thrice, and the results of one representative experiment are shown for each figure.

\section{Transfections}

MA-10 cells were cultured in 12-well plates, with $0 \cdot 2$ $\times 10^{6}$ cells/well, overnight. The cells in each well were transfected with $0.5 \mu \mathrm{g}$ DNA of the Star promoter/luciferase plasmid, PGL2/Star, expressing firefly luciferase driven by the - 966 bp sequences of the Star promoter (Caron et al. 1997). Transfections also included $6.0 \mathrm{ng}$ pRL-SV40 vector DNA (a plasmid, which constitutively expresses Renilla luciferase under the control of the SV40 promoter, Promega). Transfections were performed using FuGENE HD Transfection Reagent (Roche) following the manufacturer's instructions. After $48-\mathrm{h}$ culture, the cells were utilized for further experiments.

\section{Luciferase assays}

Following experiments, the cells were washed with cold PBS and lysed with Passive Lysis Buffer (Promega). The supernatants were utilized for luciferase assays using a Dual Luciferase Reporter Assay System following the manufacturer's instructions (Promega). The Relative Light Units (RLU, determined by dividing the reading from the PGL2/Star promoter by the reading from Renilla luciferase) were measured using a TD-20/20 luminometer (Turner Designers, Sunnyvale, CA, USA). The Star promoter activities were expressed as fold over RLU of control.

\section{Reverse transcription-PCR}

Experiments were performed for reverse transcription (RT)-PCR analyses of Star mRNA and Dax-1 (NrOb1) mRNA expressions. After experiments, MA-10 cells were washed with cold PBS and used for total RNA purification using TRIzol reagent in accordance with the manufacturer's instructions (Invitrogen). The first-strand cDNA was synthesized from the RNA using the Reverse Transcription 
A

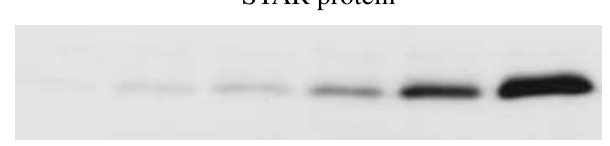

B

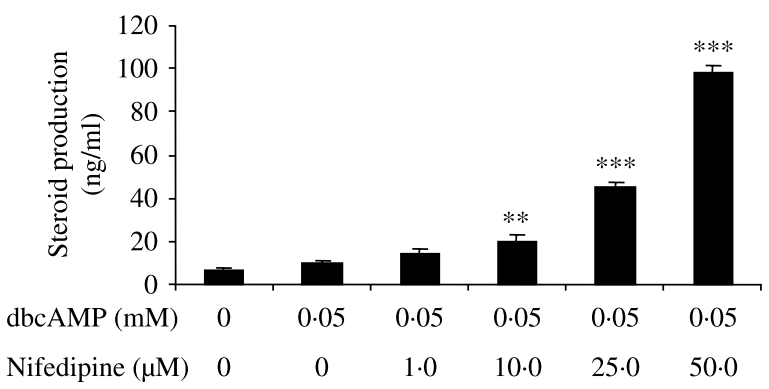

Figure 1 Blocking $\mathrm{Ca}^{2+}$ influx through L-type $\mathrm{Ca}^{2+}$ channel enhanced cAMP-induced steroidogenesis and STAR protein expression in MA-10 mouse Leydig cells. MA-10 cells were cultured in serum-free Waymouth's medium with increasing concentrations of the selective L-type $\mathrm{Ca}^{2+}$ channel blocker, nifedipine, for $30 \mathrm{~min}$, and then $0.05 \mathrm{mM}$ dbcAMP was added to the culture for $6 \mathrm{~h}$. (A) The cells were collected, and $20 \mu \mathrm{g}$ cell lysate protein was used for western blot analysis of STAR protein. (B) Progesterone concentration in the medium was assessed by RIA. $* * P<0 \cdot 01$; ${ }^{* * *} P<0 \cdot 001 ; n=3$; compared with $0 \cdot 05 \mathrm{mM}$ dbcAMP alone.

System (Promega). PCR was performed as previously described for analyses of Star mRNA (Rao et al. 2003) and Dax-1 mRNA (Jana et al. 2008). B-Actin was used as an internal marker.

\section{Quantitative real-time PCR}

Total RNA was prepared from MA-10 cells after experiments, and cDNA was synthesized from the RNA as described above. Real-time PCR was performed with the TaqMan Gene Expression Master Mix (Applied Biosystems, Foster City, CA, USA), for $10 \mathrm{~min}$ at $95^{\circ} \mathrm{C}$ for initial denaturing, followed by 40 cycles of $95^{\circ} \mathrm{C}$ for $15 \mathrm{~s}$ and $60^{\circ} \mathrm{C}$ for $1 \mathrm{~min}$ in the ABI 7900 HT Fast Real-Time PCR system (Applied Biosystems). The primer sets for the real-time PCR of mouse Dax-1, Star, and $\beta$-actin (Applied Biosystems' Assays ID: Mm00431729_m1, Mm00441558_m1, and Mm02619580_g1 respectively) were chosen from the collection of the TaqMan Gene Expression Assays (Applied Biosystems). The method of relative quantitation was used for the real-time PCR following the manufacturer's instructions.

\section{Statistical analysis}

Each experiment was repeated at least thrice. Statistical analysis of the data was performed with ANOVA followed by Tukey's significant difference test using the GraphPad Prism 4 system (GraphPad Software, San Diego, CA, USA). The data are shown as the mean \pm s.E.M.

\section{Results}

\section{Steroid hormone production}

MA-10 mouse Leydig cells were incubated with increasing concentrations of the selective L-type $\mathrm{Ca}^{2+}$ channel blocker, nifedipine, for $30 \mathrm{~min}$, followed by the addition of $0.05 \mathrm{mM}$ dbcAMP for $6 \mathrm{~h}$ to determine the effect of $\mathrm{Ca}^{2+}$ influx through L-type $\mathrm{Ca}^{2+}$ channels on steroidogenesis. The stimulation with $0.05 \mathrm{mM}$ dbAMP alone did not induce significant increase in steroidogenesis in MA-10 mouse Leydig cells, but co-incubation with nifedipine significantly increased the progesterone production in a concentration-dependent manner. Progesterone concentration in the culture medium was increased from $9 \cdot 4$ to $97.9 \mathrm{ng} / \mathrm{ml}$, as nifedipine in the culture was increased from 0 to $50 \mu \mathrm{M}$ (Fig. 1).

\section{STAR protein expression}

Western blot analyses were performed to determine whether blocking $\mathrm{Ca}^{2+}$ influx through L-type $\mathrm{Ca}^{2+}$ channels affects STAR protein expression in MA-10 cells. As shown in Fig. 1, when L-type $\mathrm{Ca}^{2+}$ channel was blocked with the increasing concentrations of nifedipine, STAR protein expression was markedly elevated in MA-10 cells cultured in the medium containing $0.05 \mathrm{mM}$ dbcAMP. The increase in STAR protein expression also occurred in a concentration-dependent manner, which was concomitant with the increase in progesterone production.

A

STAR protein

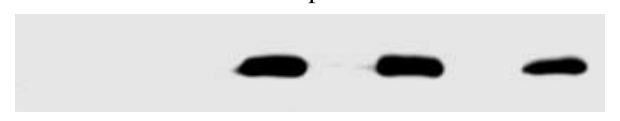

B

Progesterone production

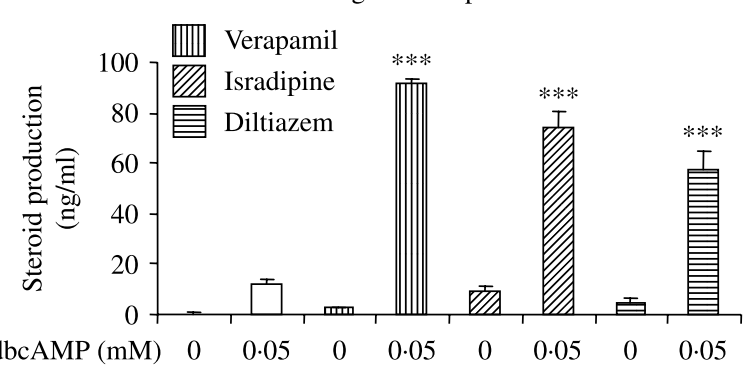

Figure 2 Effects of different L-type $\mathrm{Ca}^{2+}$ channel blockers on CAMP-induced steroidogenesis and STAR protein expression in MA-10 mouse Leydig cells. MA-10 cells were cultured in serum-free Waymouth's medium with $25 \mu \mathrm{M}$ each of the L-type $\mathrm{Ca}^{2+}$ channel blockers, verapamil, isradipine, and diltiazem respectively for $30 \mathrm{~min}$, and then $0.05 \mathrm{mM}$ dbcAMP was added to the culture for $6 \mathrm{~h}$. (A) The cells were collected and $20 \mu \mathrm{g}$ cell lysate protein was used for western blot analysis of STAR protein. (B) Progesterone concentration in the medium was assessed by RIA. ${ }^{* * *} P<0 \cdot 001$; $n=4$; compared with $0 \cdot 05 \mathrm{mM}$ dbcAMP alone. 
The increases in STAR protein expression and steroidogenesis that resulted from the blocking of L-type $\mathrm{Ca}^{2+}$ channels were confirmed by the utilization of different L-type $\mathrm{Ca}^{2+}$ channel blockers, including verapamil, isradipine, and diltiazem. Co-incubation of each blocker with $0.05 \mathrm{mM}$ dbcAMP dramatically increased STAR protein expression and steroid hormone production in MA-10 cells. Progesterone production was increased by $7 \cdot 3-, 5 \cdot 9-$, and $4 \cdot 6-$ fold respectively by verapamil, isradipine, and diltiazem over that induced by $0.05 \mathrm{mM}$ dbcAMP alone (Fig. 2).

\section{Star gene transcription}

Luciferase assays of Star promoter activity and RT-PCR analyses of Star mRNA levels were performed to understand the mechanism responsible for the inhibitory effect of $\mathrm{Ca}^{2+}$ influx through L-type $\mathrm{Ca}^{2+}$ channels on STAR protein expression. Incubation of MA-10 cells with increasing levels of nifedipine resulted in a concentration-dependent increase in Star promoter activity. The Star promoter activity increased $2 \cdot 6$-fold over controls when the concentration of nifedipine in the cultures was increased to $50 \mu \mathrm{M}$. Similarly, the results

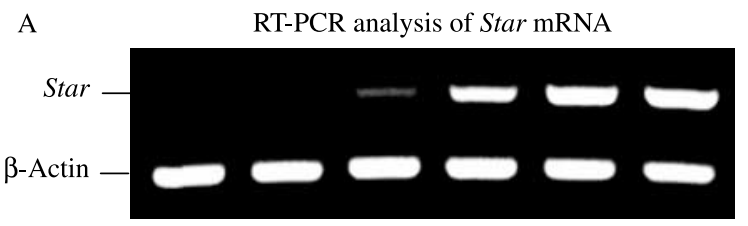

B

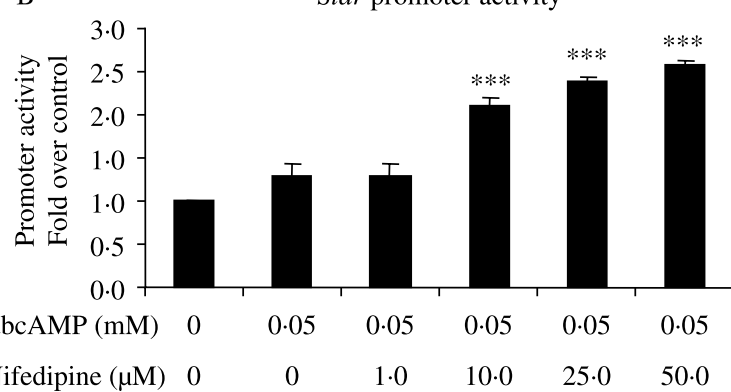

Figure 3 Blocking $\mathrm{Ca}^{2+}$ influx through L-type $\mathrm{Ca}^{2+}$ channel enhanced cAMP-induced Star gene transcription in MA-10 mouse Leydig cells. MA-10 cells were cultured in serum-free Waymouth's medium with increasing concentrations of the selective L-type $\mathrm{Ca}^{2+}$ channel blocker, nifedipine, for $30 \mathrm{~min}$, and then $0.05 \mathrm{mM}$ dbcAMP was added to the culture for $6 \mathrm{~h}$. (A) The cells were collected for total RNA isolation, and Star mRNA was analyzed by RT-PCR with $\beta$-actin as an internal marker. (B) MA-10 cells were transfected with a Star promoter/luciferase plasmid (PGL2/Star) and a pRLSV40 vector, a plasmid that constitutively expresses Renilla luciferase. The cells were then treated as described above, and the cell lysate was used for luciferase assays using a Dual-Luciferase Reporter Assay System. The Relative Light Unit (RLU) was determined by dividing the reading from the PGL2/Star promoter by the reading from Renilla luciferase. The promoter activities were expressed as fold over RLU of control. ${ }^{* * *} P<0 \cdot 001, n=3$; compared with $0 \cdot 05 \mathrm{mM}$ dbcAMP alone.
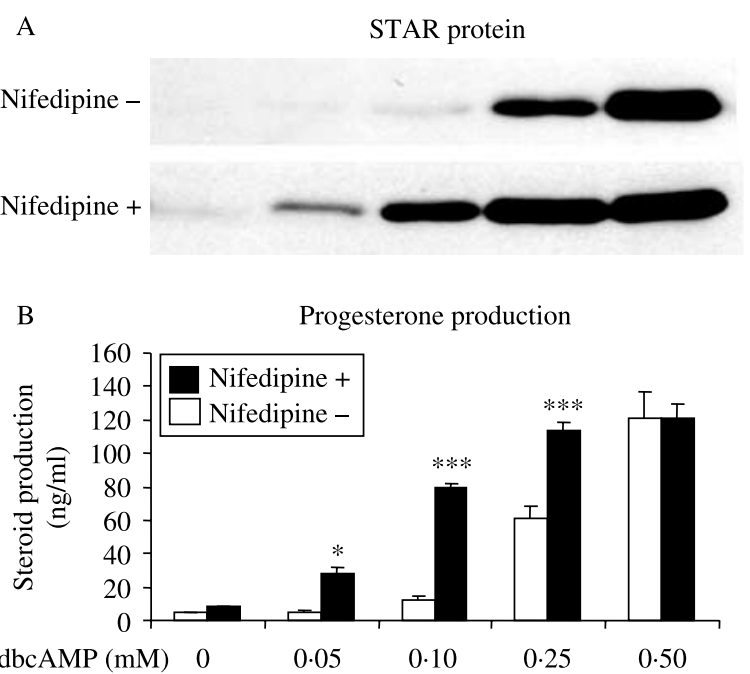

Figure 4 Synergistic interaction between nifedipine and CAMP in steroidogenesis of MA-10 mouse Leydig cells. MA-10 cells were cultured for $30 \mathrm{~min}$ in serum-free Waymouth's medium with or without $20 \mu \mathrm{M}$ nifedipine, and then increasing concentrations of dbcAMP were added to the cultures for $6 \mathrm{~h}$. (A) The cells were collected, and $20 \mu \mathrm{g}$ cell lysate protein was used for western blot analysis of STAR protein. (B) Progesterone production in the culture medium was assessed by RIA. ${ }^{*} P<0 \cdot 05 ;{ }^{* * *} P<0 \cdot 001 ; n=3$; compared with the paired group stimulated with dbcAMP alone.

obtained from RT-PCR analyses of Star mRNA showed that Star mRNA levels were increased as the levels of nifedipine in the cultures increased (Fig. 3).

\section{Synergistic interaction between nifedipine and $c A M P$}

To examine the interaction between cAMP and nifedipine, MA-10 cells were treated with or without $20 \mu \mathrm{M}$ nifedipine for $30 \mathrm{~min}$, and then increasing concentrations of dbcAMP were added to the culture medium for $6 \mathrm{~h}$. The results shown in Fig. 4 demonstrate that the sub-threshold level of dbcAMP $(0.05$ or $0.1 \mathrm{mM})$ alone was unable to stimulate significant increases in STAR protein expression and steroidogenesis. However, in the presence of $20 \mu \mathrm{M}$ nifedipine, these low levels of dbcAMP increased STAR protein expression and steroid hormone production. Similarly, while nifedipine itself did not increase STAR protein and steroid hormone synthesis, in the presence of sub-threshold levels of dbcAMP $(0.05$ or $0.1 \mathrm{mM})$, nifedipine dramatically increased STAR protein expression and progesterone production in MA-10 cells. In the cells treated with $0.1 \mathrm{mM}$ dbcAMP, nifedipine increased progesterone production $6 \cdot 6$-fold over that of cells treated with $0 \cdot 1 \mathrm{mM}$ dbcAMP alone. Although blocking $\mathrm{Ca}^{2+}$ influx through L-type $\mathrm{Ca}^{2+}$ channels enhanced cAMP-induced steroidogenesis, this effect was reduced when the levels of cAMP were higher than the threshold of STAR protein expression. When dbcAMP level in the cultures increased to $0.5 \mathrm{mM}$, nifedipine failed to increase STAR protein expression and steroid production (Fig. 4). 
Critical role of protein kinase $A$ in verapamil-enhanced steroidogenesis

The role of protein kinase A (PKA) in the verapamilenhanced steroidogenesis was investigated using the PKA inhibitor H89 or H8. While co-action of $15 \mu \mathrm{M}$ verapamil and $0.05 \mathrm{mM}$ cAMP dramatically increased STAR protein, inhibition of PKA activity with either H89 or H8 reversed this increase. Similarly, while progesterone concentration was increased from 6.6 to $86.0 \mathrm{ng} / \mathrm{ml}$ by verapamil in the same culture, it was reduced to $27 \cdot 4$ or $40.6 \mathrm{ng} / \mathrm{ml}$ by inhibition of PKA activity using H89 or H8 respectively (Fig. 5). When 22(R)hydroxylcholesterol was added to the cultures, there was no significant difference in progesterone production among the groups, indicating that the activities of steroidogenic enzymes were not affected by the treatments.

\section{Dax-1 gene transcription}

To further understand how $\mathrm{Ca}^{2+}$ influx through L-type $\mathrm{Ca}^{2+}$ channels inhibited Star gene transcription, the expression of the transcriptional repressor, DAX-1 protein, was analyzed by western blot and RT-PCR with MA-10 cells treated with verapamil and $0.05 \mathrm{mM}$ dbcAMP. Western blot analyses showed that verapamil markedly reduced DAX-1 protein. The results were verified by RT-PCR analyses of

A

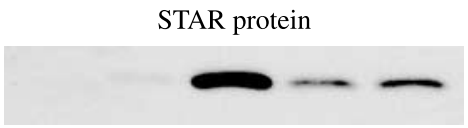

B

Progesterone production

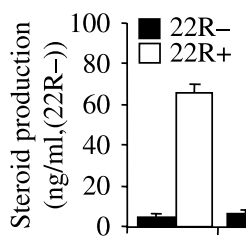

$\operatorname{dbcAMP}(\mathrm{mM}) \quad 0$

Verapamil $(\mu \mathrm{M}) \quad 0$

$\mathrm{H} 89(\mu \mathrm{M})$

$\mathrm{H} 8(\mu \mathrm{M})$

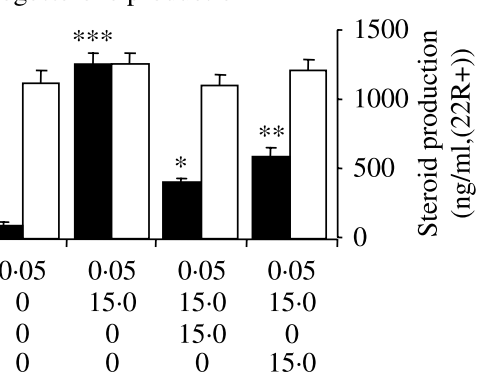

Figure 5 Inhibition of protein kinase A activity reversed the verapamil-enhanced steroidogenesis and STAR protein expression. MA-10 cells were cultured in serum-free Waymouth's medium with $15 \mu \mathrm{M}$ of the selective L-type $\mathrm{Ca}^{2+}$ channel blocker, verapamil, and $15 \mu \mathrm{M}$ of PKA inhibitor H89 or $\mathrm{H} 8$ for $30 \mathrm{~min}$, and then $0.05 \mathrm{mM}$ dbcAMP was added to the culture for $6 \mathrm{~h}$. (A) The cells were collected, and $20 \mu \mathrm{g}$ cell lysate protein was used for western blot analysis of STAR protein. (B) MA-10 cells were cultured in the medium with or without $25 \mu \mathrm{M} 22$ (R)hydroxycholesterol $(22 \mathrm{R}+$ or $22 \mathrm{R}-$ ) and then treated as described above. The medium was collected, and progesterone concentration in the medium was assessed by RIA. ${ }^{*} P<0 \cdot 05 ;{ }^{*} P<0 \cdot 01 ; n=3$; compared with the cells treated with $0.05 \mathrm{mM}$ dbcAMP alone. ${ }^{* *} P<0 \cdot 001 ; n=3$; compared with the cells treated with $\mathrm{H} 89$ or $\mathrm{H} 8$. In the presence of 22(R)hydroxylcholesterol in the cultures, there was no significant difference in progesterone production among the treatments.
A

DAX-1 protein

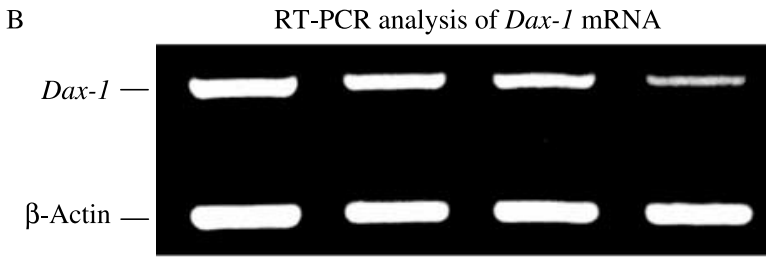

C

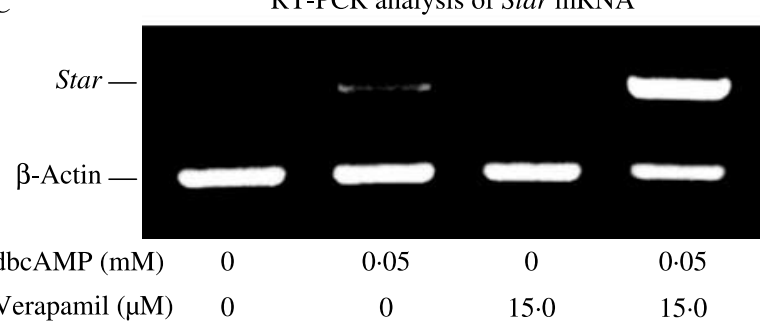

Figure 6 Blocking $\mathrm{Ca}^{2+}$ influx through L-type $\mathrm{Ca}^{2+}$ channel depressed Dax-1 gene expression in MA-10 mouse Leydig cells. MA-10 cells were cultured in serum-free Waymouth's medium with $15 \mu \mathrm{M}$ of the selective L-type $\mathrm{Ca}^{2+}$ channel blocker, verapamil, for $30 \mathrm{~min}$, and then $0.05 \mathrm{mM}$ dbcAMP was added to the cultures for $6 \mathrm{~h}$. (A) The cells were collected, and $20 \mu \mathrm{g}$ cell lysate protein was used for western blot analysis of DAX-1 protein. (B and C) The cells were collected for total RNA isolation. Dax-1 mRNA and Star mRNA were analyzed by RT-PCR with $\beta$-actin as an internal marker.

Dax-1 mRNA, which indicated that blocking L-type $\mathrm{Ca}^{2+}$ channel inhibited Dax-1 gene transcription. When DAX-1 protein and mRNA were reduced, Star mRNA level increased dramatically (Fig. 6). The observations were further confirmed by quantitative real-time PCR analyses of Dax-1 mRNA and Star mRNA, with Dax-1 mRNA level being reduced and Star mRNA level being increased significantly by blocking L-type $\mathrm{Ca}^{2+}$ channels (Fig. 7).

\section{Discussion}

Previous studies suggested that $\mathrm{Ca}^{2+}$ influx through L-type $\mathrm{Ca}^{2+}$ channels may produce differential effects on Star gene expression in Leydig cells (Manna et al. 1999, Chen et al. 2007). The present study further indicates that $\mathrm{Ca}^{2+}$ influx through L-type $\mathrm{Ca}^{2+}$ channels is involved in an inhibitory effect on Star gene expression and regulates the sensitivity of Leydig cells to cAMP stimulation.

The inhibitory effect generated by $\mathrm{Ca}^{2+}$ influx through L-type $\mathrm{Ca}^{2+}$ channels on Star gene expression was demonstrated by three lines of evidence: 1) blocking $\mathrm{Ca}^{2+}$ influx through L-type $\mathrm{Ca}^{2+}$ channels with increasing levels of a selective blocker, nifedipine, induced a concentrationdependent increase in STAR protein expression in the cells 
A Real-time PCR analysis of Dax-1 mRNA

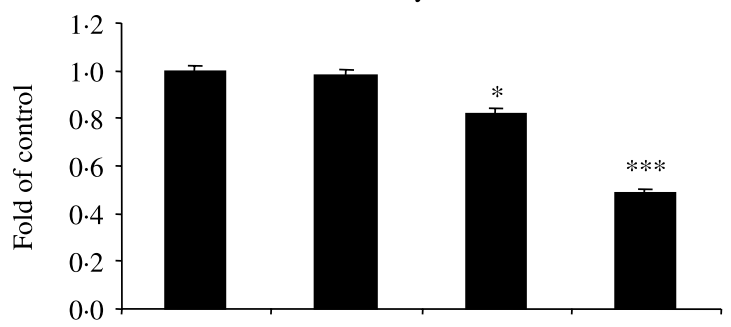

B

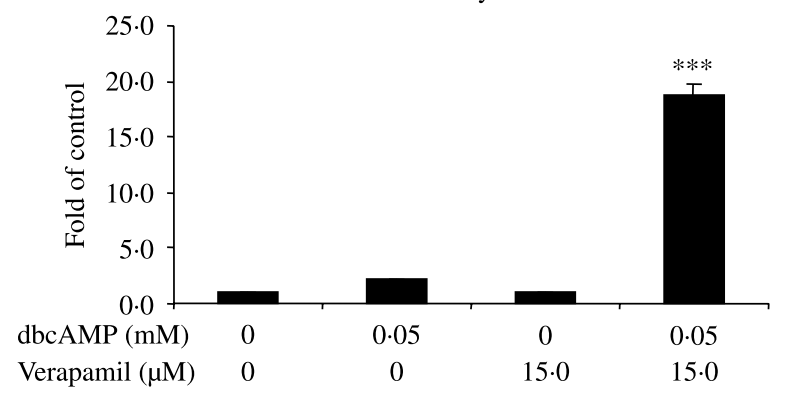

Figure 7 Real-time PCR analyses of Dax-1 mRNA and Star mRNA in MA-10 mouse Leydig cells treated with verapamil. MA-10 cells were cultured in serum-free Waymouth's medium with $15 \mu \mathrm{M}$ of the selective L-type $\mathrm{Ca}^{2+}$ channel blocker, verapamil, for $30 \mathrm{~min}$, and then $0.05 \mathrm{mM}$ dbcAMP was added to the cultures for $6 \mathrm{~h}$. The total RNA was isolated from the cells. The cDNA was synthesized from the RNA for real-time PCR analyses of Dax-1 mRNA and Star mRNA, with $\beta$-actin as an internal marker. The levels of Dax-1 mRNA and Star mRNA were adjusted by $\beta$-actin mRNA levels and expressed as fold of control. (A) For Dax-1 mRNA: ${ }^{*} P<0 \cdot 05 ; n=4$; compared with control. ${ }^{* *} P<0 \cdot 001 ; n=4$; compared with the cells treated with $0.05 \mathrm{mM}$ dbcAMP alone or verapamil alone. (B) For Star mRNA: ***P<0*001; $n=4$; compared with the cells treated with $0.05 \mathrm{mM}$ dbcAMP alone or verapamil alone.

treated with $0.05 \mathrm{mM}$ dbcAMP. Progesterone production by the cells was also increased, as STAR protein expression was enhanced by nifedipine; 2) the inhibitory effect generated by $\mathrm{Ca}^{2+}$ influx through L-type $\mathrm{Ca}^{2+}$ channels on STAR protein expression was confirmed by the experiments utilizing three different selective L-type $\mathrm{Ca}^{2+}$ channel blockers, verapamil, isradipine, and diltiazem respectively. Incubation of MA-10 cells with $25 \mu \mathrm{M}$ each of the blockers produced similar steroidogenic results, with each of them dramatically enhancing STAR protein expression and progesterone production; 3 ) the observations with nifedipine were corroborated by RT-PCR analyses of Star mRNA and also by the luciferase assays of Star promoter activity in the cells co-incubated with nifedipine and $0.05 \mathrm{mM}$ dbcAMP, with both Star mRNA level and promoter activity being increased by the treatments. The results indicated that blocking L-type $\mathrm{Ca}^{2+}$ channels enhanced Star gene transcription. Similar inhibitory effect of $\mathrm{Ca}^{2+}$ influx through L-type $\mathrm{Ca}^{2+}$ channel on steroidogenesis was also reported in other types of steroidogenic cells (Barrett et al. 1991, 1995, Rossier et al. 1996).
The results from the present study further indicated that this inhibition on Star gene expression by $\mathrm{Ca}^{2+}$ influx through L-type $\mathrm{Ca}^{2+}$ channels was involved in regulating the sensitivity of Leydig cells to cAMP stimulation. Under normal circumstances, sub-threshold levels of cAMP $(0 \cdot 05$ and $0.1 \mathrm{mM}$ cAMP) are unable to induce STAR protein expression or a significant increase in progesterone production in MA-10 cells. However, in the presence of L-type $\mathrm{Ca}^{2+}$ channel blockers, the effectiveness of cAMP was dramatically increased, with $0.05 \mathrm{mM}$ cAMP being able to induce a marked increase in STAR protein expression and also a significant increase in steroid hormone production. On the other hand, in the absence of these low levels of cAMP, blocking $\mathrm{Ca}^{2+}$ influx through L-type $\mathrm{Ca}^{2+}$ channels did not induce Star gene expression and steroidogenesis in MA-10 cells. We also observed that inhibition of PKA activity reversed the verapamil-increased STAR protein and progesterone production. These observations suggest that blocking L-type $\mathrm{Ca}^{2+}$ channels alone is unable to stimulate steroidogenesis. However, the blockers did attenuate the inhibitory effect and lowered the threshold of cAMPstimulated STAR protein expression. Therefore, subthreshold levels of cAMP are able to induce maximal levels of Star gene expression and steroid hormone production.

To understand how the $\mathrm{Ca}^{2+}$ influx through L-type $\mathrm{Ca}^{2+}$ channels generated the inhibitory effect on Star gene transcription and reduced the sensitivity of Leydig cells to cAMP stimulation, expression of DAX-1 protein, a transcriptional repressor of Star gene transcription, was examined. The results from western blot analyses showed that blocking $\mathrm{Ca}^{2+}$ influx through L-type $\mathrm{Ca}^{2+}$ channels reduced DAX-1 protein. This observation was confirmed by RT-PCR and real-time PCR analyses of Dax-1 mRNA, with the level of Dax-1 mRNA being reduced by blocking L-type $\mathrm{Ca}^{2+}$ channels in MA-10 cells cultured in the medium containing $0.05 \mathrm{mM}$ cAMP, suggesting that $\mathrm{Ca}^{2+}$ influx through L-type $\mathrm{Ca}^{2+}$ channels acted at the transcriptional level of Dax-1 gene expression. As shown in the present and previous studies (Wang et al. 2008), DAX-1 protein is constitutively expressed and maintained at a high level in MA-10 cells. DAX-1 generates a tonic inhibition on Star gene expression by binding to a hairpin structure in the Star promoter and depressing Star gene transcription (Zazopoulos et al. 1997). In addition, DAX-1 expression is able to reduce the level of steroidogenic factor-1 (SF-1) protein, an important transcriptional factor in Star gene expression, and also represses the transactivation potential of SF-1 on Star gene transcription (Manna et al. 2009). Thus, reduction in DAX-1 protein by blocking L-type $\mathrm{Ca}^{2+}$ channels attenuated the tonic inhibition of DAX-1 protein and increased the sensitivity of Leydig cells to cAMP stimulation.

These observations and previous studies indicated that $\mathrm{Ca}^{2+}$ influx through L-type $\mathrm{Ca}^{2+}$ channels not only produced positive effect (Manna et al. 1999), but also produced negative effect on Star gene expression. As described above, the negative effect resulted from the role 
of $\mathrm{Ca}^{2+}$ influx through L-type $\mathrm{Ca}^{2+}$ channels in maintaining DAX-1 expression when cAMP levels were below the threshold of Star gene expression. This can be seen from the present study that blocking L-type $\mathrm{Ca}^{2+}$ channels using the blocker markedly reduced DAX-1 protein and increased Star gene expression. However, the steroidogenic effect of the L-type $\mathrm{Ca}^{2+}$ channel blocker is affected by the levels of cAMP. As concentrations of cAMP in the cultures increased to produce maximal level of STAR protein expression, cAMP stimulation reduces DAX-1 protein to the low levels (Jo \& Stocco 2004, Manna et al. 2009), and also increases positive signals, including $\mathrm{Ca}^{2+}$ (Sullivan \& Cooke 1986). Since DAX-1 protein was already reduced to such a low level, blocking L-type $\mathrm{Ca}^{2+}$ channel might not be able to effectively further reduce the inhibitory effect of DAX-1 protein, but reduced the positive effect of the $\mathrm{Ca}^{2+}$ influx through L-type $\mathrm{Ca}^{2+}$ channels on Star gene expression as previously reported (Manna et al. 1999).

In summary, the present study demonstrated that blocking L-type $\mathrm{Ca}^{2+}$ channels enhanced cAMP-induced Star gene transcription, STAR protein expression, and progesterone production in MA-10 mouse Leydig cells, indicating a role for $\mathrm{Ca}^{2+}$ influx through L-type $\mathrm{Ca}^{2+}$ channels in an inhibition of Star gene expression and steroidogenesis. This inhibitory effect may involve a role of $\mathrm{Ca}^{2+}$ influx through L-type $\mathrm{Ca}^{2+}$ channels in the regulation of Dax-1 gene expression.

\section{Declaration of interest}

The authors declare that there is no conflict of interest that would prejudice the impartiality of this scientific work.

\section{Funding}

The authors would like to acknowledge the support of NIH Grant AG025349 to XJW.

\section{References}

Ascoli M 1981 Characterization of several clonal lines of cultured Leydig tumor cells: gonadotropin receptors and steroidogenic responses. Endocrinology 108 88-95.

Barrett PQ, Isales CM, Bollag WB \& McCarthy RT $1991 \mathrm{Ca}^{2+}$ channels and aldosterone secretion: modulation by $\mathrm{K}^{+}$and atrial natriuretic peptide. American Journal of Physiology 261 F706-F719.

Barrett PQ, Ertel EA, Smith MM, Nee JJ \& Cohen CJ 1995 Voltage-gated calcium currents have two opposing effects on the secretion of aldosterone. American Journal of Physiology 268 C985-C992.

Caron KM, Ikeda Y, Soo SC, Stocco DM, Parker KL \& Clark BJ 1997 Characterization of the promoter region of the mouse gene encoding the steroidogenic acute regulatory protein. Molecular Endocrinology 11 138-147.

Chen YC, Nagpal ML, Stocco DM \& Lin T 2007 Effects of genistein, resveratrol, and quercetin on steroidogenesis and proliferation of MA-10 mouse Leydig tumor cells. Journal of Endocrinology 192 527-537.

Clark BJ, Wells J, King SR \& Stocco DM 1994 The purification, cloning, and expression of a novel luteinizing hormone-induced mitochondrial protein in MA-10 mouse Leydig tumor cells. Characterization of the steroidogenic acute regulatory protein (STAR). Journal of Biological Chemistry 269 28314-28322.

Cooke BA 1999 Signal transduction involving cyclic AMP-dependent and cyclic AMP-independent mechanisms in the control of steroidogenesis. Molecular and Cellular Endocrinology 151 25-35.

Hales KH, Diemer T, Ginde S, Shankar BK, Roberts M, Bosmann HB \& Hales DB 2000 Diametric effects of bacterial endotoxin lipopolysaccharide on adrenal and Leydig cell steroidogenic acute regulatory protein. Endocrinology 141 4000-4012.

Hall PF, Osawa S \& Mrotek J 1981 The influence of calmodulin on steroid synthesis in leydig cells from rat testis. Endocrinology 109 1677-1682.

Jana K, Yin X, Schiffer RB, Chen JJ, Pandey AK, Stocco DM, Grammas P \& Wang X 2008 Chrysin, a natural flavonoid enhances steroidogenesis and steroidogenic acute regulatory protein gene expression in mouse Leydig cells. Journal of Endocrinology 197 315-323.

Janszen FH, Cooke BA, Van Driel MJ \& Van Der Molen HJ 1976 The effect of calcium ions on testosterone production in Leydig cells from rat testis. Biochemical Journal 160 433-437.

Jo Y \& Stocco DM 2004 Regulation of steroidogenesis and steroidogenic acute regulatory protein in R2C cells by DAX-1 (dosage-sensitive sex reversal, adrenal hypoplasia congenita, critical region on the $\mathrm{X}$ chromosome, gene-1). Endocrinology 145 5629-5637.

Kumar S, Blumberg DL, Canas JA \& Maddaiah VT 1994 Human chorionic gonadotropin (hCG) increases cytosolic free calcium in adult rat Leydig cells. Cell Calcium 15 349-355.

Lin D, Sugawara T, Strauss JF III, Clark BJ, Stocco DM, Saenger P, Rogol A \& Miller WL 1995 Role of steroidogenic acute regulatory protein in adrenal and gonadal steroidogenesis. Science 267 1828-1831.

Manna PR, Pakarinen P, El-Hefnawy T \& Huhtaniemi IT 1999 Functional assessment of the calcium messenger system in cultured mouse Leydig tumor cells: regulation of human chorionic gonadotropin-induced expression of the steroidogenic acute regulatory protein. Endocrinology 140 1739-1751.

Manna PR, Dyson MT, Jo Y \& Stocco DM 2009 Role of dosage-sensitive sex reversal, adrenal hypoplasia congenita, critical region on the $\mathrm{X}$ chromosome, gene 1 in protein kinase A- and protein kinase C-mediated regulation of the steroidogenic acute regulatory protein expression in mouse Leydig tumor cells: mechanism of action. Endocrinology $\mathbf{1 5 0}$ 187-199.

Meikle AW, Liu XH \& Stringham JD 1991 Extracellular calcium and luteinizing hormone effects on 22-hydroxycholesterol used for testosterone production in mouse Leydig cells. Journal of Andrology 12 148-151.

Moger WH 1983 Effects of the calcium-channel blockers cobalt, verapamil, and D600 on Leydig cell steroidogenesis. Biology of Reproduction $\mathbf{2 8}$ 528-535.

Payne AH \& Youngblood GL 1995 Regulation of expression of steroidogenic enzymes in Leydig cells. Biology of Reproduction 52 217-225.

Pereira ME, Segaloff DL \& Ascoli M $1988 \mathrm{Ca}^{2+}$ is an inhibitor of adenylate cyclase in MA-10 Leydig tumor cells. Endocrinology $\mathbf{1 2 2}$ 2232-2239.

Ramnath HI, Peterson S, Michael AE, Stocco DM \& Cooke BA 1997 Modulation of steroidogenesis by chloride ions in MA-10 mouse tumor Leydig cells: roles of calcium, protein synthesis, and the steroidogenic acute regulatory protein. Endocrinology 138 2308-2314.

Rao RM, Jo Y, Leers-Sucheta S, Bose HS, Miller WL, Azhar S \& Stocco DM 2003 Differential regulation of steroid hormone biosynthesis in R2C and MA-10 Leydig tumor cells: role of SR-B1-mediated selective cholesteryl ester transport. Biology of Reproduction 68 114-121.

Resko JA, Norman RL, Niswender GD \& Spies HG 1974 The relationship between progestins and gonadotropins during the late luteal phase of the menstrual cycle in rhesus monkeys. Endocrinology 94 128-135.

Rossier MF, Burnay MM, Vallotton MB \& Capponi AM 1996 Distinct functions of T- and L-type calcium channels during activation of bovine adrenal glomerulosa cells. Endocrinology 137 4817-4826. 
Sullivan MH \& Cooke BA 1986 The role of $\mathrm{Ca}^{2+}$ in steroidogenesis in Leydig cells. Stimulation of intracellular free $\mathrm{Ca}^{2+}$ by lutropin (LH), luliberin (LHRH) agonist and cyclic AMP. Biochemical Journal 236 45-51.

Townson DH, Wang XJ, Keyes PL, Kostyo JL \& Stocco DM 1996 Expression of the steroidogenic acute regulatory protein in the corpus luteum of the rabbit: dependence upon the luteotropic hormone, estradiol-17 $\beta$. Biology of Reproduction 55 868-874.

Wang XJ \& Stocco DM 1999 Cyclic AMP and arachidonic acid: a tale of two pathways. Molecular and Cellular Endocrinology 158 7-12.

Wang XJ, Liu Z, Eimerl S, Timberg R, Weiss AM, Orly J \& Stocco DM 1998 Effect of truncated forms of the steroidogenic acute regulatory protein on intramitochondrial cholesterol transfer. Endocrinology 139 3903-3912.
Wang X, Yin X, Schiffer RB, King SR, Stocco DM \& Grammas P 2008 Inhibition of thromboxane a synthase activity enhances steroidogenesis and steroidogenic acute regulatory gene expression in MA-10 mouse Leydig cells. Endocrinology 149 851-857.

Zazopoulos E, Lalli E, Stocco DM \& Sassone-Corsi P 1997 DNA binding and transcriptional repression by DAX-1 blocks steroidogenesis. Nature 390 311-315.

Received in final form 5 October 2009

Accepted 12 October 2009

Made available online as an Accepted Preprint 12 October 2009 